\title{
The endophytic bacteria producing IAA (Indole Acetic Acid) in Arachis hypogaea
}

\author{
LINA HERLINA, KRISPINUS KEDATI PUKAN, DEWI MUSTIKANINGTYAS ${ }^{\bullet \bullet}$ \\ Department of Biology, Faculty of Mathematics and Natural Sciences, Universitas Negeri Semarang. Kampus Unnes Sekaran, Gunungpati, Kota \\ Semarang City 50229, Central Java, Indonesia. Tel.: +62-24-8508112, •email: linaarsip@yahoo.co.id, •`dewi_mustikaningtyas@mail.unnes.ac.id
}

Manuscript received: 6 November 2016. Revision accepted: 25 June 2017.

\begin{abstract}
Herlina L, Pukan KK, Mustikaningtyas D. 2017. The endophytic bacteria producing IAA (Indole Acetic Acid) in Arachis hypogaea. Cell Biol Dev 1: 31-35. Endophytic bacteria live in plant tissue and form colonies without harming the host. Every cormophyte with a stem and root may contain some endophytic bacteria that can produce biological compounds or secondary metabolites. The objective of the study was to obtain endophytic bacteria isolates from peanut plants (Arachis hypogaea) at three locations, to test in vitro the ability of endophytic bacteria isolates to produce IAA, and also to analyze IAA on the growth and development of mungbean plants. The study was carried out in three stages; the first was the isolation of endophytic bacteria from the leaves, stems, and roots; the second was the test of in vitro endophytic bacteria isolates to understand the ability of IAA production. IAA assay was measured using a spectrophotometer with a wavelength of $535 \mathrm{~nm}$; the third was the introduction of IAA-producing endophytic bacteria in mungbean. The parameters observed were the length of sprouts and the number of lateral roots. The results showed that 16 isolates were selected based on IAA-producing ability. The isolates could produce different IAA with different morphological characteristics. After the fourth day of incubation, the highest and lowest IAA amounts were $69.68\left(\mathrm{mg} \mathrm{L}^{-1}\right)$ and $8.50(\mathrm{mg}$ $\mathrm{L}^{-1}$ ), respectively. Isolates that produce high IAA levels are applied to mungbean; it affects the number of lateral roots but does not affect the length of the sprouts. DM and K1K1 isolates have the effect of increasing lateral root formation and are expected to be potential sources of bioactive metabolites.
\end{abstract}

Keywords: Endophytic bacteria, IAA, Arachis hypogaea

\section{INTRODUCTION}

Endophytic bacteria are microbes that live in tissues that form colonies in plant tissues without harming the host. Each high-level plant may contain several endophytic bacteria capable of producing biological compounds or secondary metabolites suspected as a result of coevolution or transfer genetics from host plants to endophytic microbes (Duan et al., 2013). The biological association between endophytic microbes and host plants varies from neutral, commensalism to symbiosis. Plants are a food source for endophytic microbes in completing their life cycle. Endophytic bacteria can be isolated from the surfaces of sterile plant tissue or extracted from inner plant tissues (Pandey et al., 2012; Ryan et al., 2008). In particular, bacteria enter the tissues through germinated tissue, roots, stomata, and damaged tissue. In recent years, endophytic bacteria have been used as biofertilizers to increase crop production, significantly reducing the chemical input to the environment (Luo et al., 2012; Ahemad et al., 2014).

Endophytic bacteria is one of the microorganisms that are now beginning to develop its role in increasing plant growth through its ability to produce growth hormone and N2 retardation from the air. The ability of endophytic microorganisms to produce plant hormones, such as IAA (Indole Acetic Acid) or auxin, can help plants grow better, as in some food crops such as peanuts, corn, wheat, and sugarcane (Mattos et al. 2008). Auxin-producing endophytic bacteria can help plants to grow and develop in addition to endogenous auxin possessed by plants. Auxin in plants is usually present in meristem tissues (Spaepen et al. 2007). Auxin produced by endophytic bacteria Burkholderia kururiensis in peanut plants causes plant growth to be better with the number of roots, increasing the plant's lateral roots. As a result, plant growth is rapid, giving high-yielding products (Mattos et al. 2008).

The mechanism of increasing plant growth by endophytic bacteria can occur in several ways, including folic, nitrogen fixation, stimulation of lateral root growth, and production of growth hormones such as auxin, ethylene, and cytokines (Ahemad et al. 2014). Plants meet the needs of hormones through their ability to synthesize the auxin hormone from microorganisms in their tissues. Therefore, IAA-producing bacteria potentially join the physiological process of plants by entering IAA-generated crops. The effect on the plant is that it is more sensitive to altering its IAA concentrations, thus helping to form lateral roots, adventitious roots, and primary root elongation (Ryan et al. 2008).

Various research results reported that some groups of microbes are capable of producing compounds that can accelerate plant growth. Some soil microorganisms that produce IAA, such as Stenotrophomonas maltophilia from the banana root, can promote plant growth (Ambawade and Pathade, 2015). Azospirillum, which produces IAA, can 
accelerate plant growth and lateral root development and stimulate density and root hair length, leading to increased nutrient uptake in peanut crops to increase peanut plant height and make this bacteria function as bacterial fertilizer (Lestari et al. 2007). The effect of Azotobacter in increasing root biomass is due to the income of (Indol Acetic Acid) in the root zone. IAA-producing endophytic bacteria successfully isolated from plant roots are Agrobacterium tumefaciens and Azotobacter vinelandii (Khan and Doty 2009). Different bacterial groups were reported to produce IAA (indole-3-acetic acid) and the most important auxin that regulates plant development, such as cell extension, cleavage, differentiation, gene regulation, and other tropical responses (Nath et al. 2013).

Auxin is one hormone that can stimulate plant growth by increasing the elongation process, stem extension, and cell differentiation (Tarably et al. 2008). In the IAA plant, the tissue is synthesized in various parts of the plant body. Generally, IAA was mostly produced in the growing parts of plants. Tryptophan is a precursor in auxin biosynthesis both in plants and in microorganisms. Tryptophan contains active compounds that spur the growth of rhizosphere microbes and endophytes. Suitable precursors are a primary factor in the microbial secretion of secondary metabolites. IAA microbial biosynthesis in soil may be driven by the presence of tryptophan originating from root exudates or damaged cells (Spaepen et al., 2007). The purpose of this research is to isolate and identify IAA-producing endophytic bacteria, which are expected to influence green beans' growth and development.

\section{MATERIALS AND METHODS}

\section{The isolation of endophytic bacteria from Arachis hypogaea}

The roots and leaves of the peanut were cleaned for about 20 minutes using running water. Next, roots and leaves were sterilized by soaking them in alcohol solution $70 \%$ for 2 minutes, hypochlorite solution $5 \%$ for 5 minutes, and alcohol solution $70 \%$ for 30 seconds, and then were rinsed with sterile distilled water twice (RaduandKqueen, 2002). After sterilizing, the roots and leaves were aseptically mashed in a mortar, then put into a test tube containing sterile distilled water in a ratio of 1: 10 and diluted to 103 . Next, $1 \mathrm{ml}$ of the roots and leaves were spread on a nutrient medium for sterilizing and incubating at room temperature for 24 hours. Next, the growing bacteria colonies were subcultured into the same medium to obtain pure cultures. Finally, the characterization of colony morphology gram stain and some biochemical tests were conducted to distinguish bacterial isolates from one another.

\section{The in vitro process for producing IAA of endophytic bacteria}

The in vitro process for producing IAA of endophytic bacteria was done by generating the bacteria in media containing tryptophan $3 \mathrm{ml}$ bacterial suspension, with some cells of $10^{8} \mathrm{CFU} / \mathrm{ml} /$ equal to McFarland (Bresson and
Borges, 2004) inoculated into $30 \mathrm{ml}$ of Luria-Bertani Tryptophan solution. At room temperature, bacterial cultures were incubated and shaken at $150 \mathrm{rpm}$ for 7 days. The IAA level generated during cultivation was measured every two days a week. The IAA level was measured in colorimetry with a spectrophotometer at $535 \mathrm{~nm}$ wavelength. Culture fluid was centrifuged for 25 minutes at $5,000 \mathrm{rpm}$. The obtained filtrate was mixed with the Salkowski reagent ( $150 \mathrm{ml}$ concentrated $\mathrm{H}_{2} \mathrm{SO} 4,250 \mathrm{ml}$ of distilled water, $7.5 \mathrm{ml}$ of $0.5 \mathrm{MFeCl}_{3} \cdot 6 \mathrm{H}_{2} \mathrm{O}$ ) with a ratio of $2: 1$. The mixture was then incubated in room temperature for an hour before the absorbance was measured at a wavelength of $535 \mathrm{~nm}$. IAA level produced by endophytic bacteria was determined from the linear plot of the absorbance value of a standard IAA.

\section{Introduction of IAA-producing endophytic bacteria in mungbean plants}

The positive bacterial culture produced IAA was tested in liquid and solid to grow the mungbean plant. The introduction of endophytic bacteria is done on a sterile mungbean sprout. To get sterile sprouts then, mungbean seeds were grown in sterile media. First, the surface of mungbean seeds is washed under running water. Then, the seeds are soaked in a mixture of Agrep (fungicide) solution with two drops of $80 \%$ tween solution and incubated for 30 minutes at $120 \mathrm{rpm}$. Next, the seeds were washed with sterile distilled water, soaked with $10 \%$ chlorox solution with a shaker for 15 minutes, and washed with sterile distilled water three times. Next, the seeds were soaked with $5 \%$ chlorox solution with a shaker for 15 minutes, and then they were washed with sterile distilled three times. In the last stage, the seeds were soaked in $70 \%$ alcohol for one minute and rinsed with sterile distilled. Seeds of sterile mungbean were grown in an agar medium. The seeds were grown for one week and placed in a room with less light, and then the young sprouts were transferred into a sterile container.

The sprouts are immersed into a production suspension that has equalized the turbidity with an Mc. Farland solution $\left(10^{8}\right.$ cells $\left./ \mathrm{ml}\right)$ for one hour with $50 \%$ dilution. Sprouts soaked with aquades were used as controls. Each treatment was repeated six times. Any sprouts immersed in a production suspension are grown on sterile soil media in polybags. The growing sprouts are observed after one week. The parameters observed were the length of sprouts, the number of lateral roots, and the wet weight of the plant.

\section{RESULTS AND DISCUSSION}

\section{The isolation of endophytic bacteria from Arachis hypogaea}

The isolation results from three locations, Gunungpati, Pakintelan, and Klipang, earned 22 endophytic bacterial isolates. After examining the bacteria producing IAA, 16 isolates have the ability to produce IAA (Table. 1). Based on the characterization result in table 1 , it could describe that the isolates have a variation of colony morphology. Most of them are Gram-negative bacteria, and the cell 
morphology is coccus and bacillus. It means that the 16 isolates may be different species or different genera. Further research is needed to identify the isolates bacteria species.

\section{The ability of endophytic bacteria to produce IAA with the invitro process}

Variation was found in the abilities of endophytic bacteria in producing IAA, depending on its isolates and the age of cultures, as presented in Figure 1. This figure shows that the production of IAA by bacteria is mostly (10 isolates) on the fourth day after incubation. While on isolate GNP1K2 and P1K2 IAA, production increased with increasing culture time. 4 isolates, i.e., GNP4K1, K1K2, GNP1K1, and GNP2K2, experienced the highest IAA production on the second day. This difference is thought to be due to variations in the type of bacteria and location. The production of IAA by bacteria varies due to environmental factors, growth rates, availability of amino acids, and other $\mathrm{N}$ sources (Yurnaliza. 2010). The decrease in IAA levels on the fourth or sixth day is due to the available nutrients (tryptophan), which have begun to decrease.
The use of nutrients in every bacterium varies. In some isolates, it increases in line with incubation time because the enzyme that converts tryptophan to IAA is still low at the time of incubation on the second day. In line with bacterial growth rate, the enzyme used to convert tryptophan to IAA is active enough to produce high IAA (Taghavi et al., 2009). It has been reported that endophytic bacteria produce significant IAA in B. cereus (Rana et al., 2011.) and P. putida (Jasim et al., 2013). The production rate was found to be maximal in the case of $P$. putida (ECL5) and minimum in C. michiganensis (ECL6) in the presence of tryptophan. IAA is the most common plant hormone, which stimulates plant growth and reproduction (Taghavi et al. 2009). IAA produced by bacteria interacts with plants in various pathogenesis and phytostimulation. IAA is a major auxin in plants involved in cell enlargement and division, tissue differentiation, and physiological processes (Spaepen et al., 2007). The amount of IAA produced by bacteria plays an important role in the interaction of microbial plants. Plant growth modulation was performed with optimal IAA concentration range.

Table 1. Characteristics of bacteria producing IAA

\begin{tabular}{|c|c|c|c|c|c|c|c|c|}
\hline \multirow[b]{2}{*}{ Isolate } & \multicolumn{6}{|c|}{ The colony morphology } & \multirow[b]{2}{*}{ Gram } & \multirow{2}{*}{$\begin{array}{c}\text { Cells } \\
\text { morphology }\end{array}$} \\
\hline & Size & $\begin{array}{c}\text { Optical } \\
\text { characteristic }\end{array}$ & Shape & Elevation & Texture & Margins & & \\
\hline K1K1 & Moderate & Translucent & Circular & Raised & Glisten & Serrate & - & Coccus \\
\hline AT & Pinpoint & Translucent & Circular & Convex & Smoothly glisten & Entire & - & Bacillus \\
\hline $\mathrm{P} 1 \mathrm{~K} 2$ & Moderate & Translucent & Circular & Raised & Smoothly glisten & Undulate & - & Coccus \\
\hline $\mathrm{DM}$ & Moderate & Translucent & Circular & Raised & Glisten & Undulate & - & Bacillus \\
\hline GNP2K22 & Moderate & Translucent & Circular & Raised & Glisten & Undulate & - & Coccus \\
\hline DTR & Small & Translucent & Circular & Raised & Glisten & Undulate & - & Bacillus \\
\hline $\mathrm{P} 2 \mathrm{~K} 3$ & Small & Translucent & Circular & Raised & Glisten & Undulate & + & Bacillus \\
\hline $\mathrm{K} 1 \mathrm{~K} 2$ & Small & Translucent & Irregular & Raised & Glisten & Undulate & - & Coccus \\
\hline GNP2K2 & Moderate & Translucent & Circular & Raised & Glisten & Undulate & - & Bacillus \\
\hline GNP2K21 & Small & Translucent & Circular & Convex & Smoothly glisten & Entire & - & Bacillus \\
\hline GNP1K1 & Pinpoint & Translucent & Circular & Raised & Glisten & Undulate & - & Bacillus \\
\hline BPK3 & Moderate & Translucent & Circular & Raised & Glisten & Serrate & - & Coccus \\
\hline GNP1K2 & Large & Translucent & Circular & Raised & Glisten & Entire & - & Bacillus \\
\hline GNP2K1 & Small & Translucent & Circular & Raised & Glisten & Entire & - & Bacillus \\
\hline GNP3K1 & Small & Translucent & Circular & Raised & Glisten & Entire & - & Bacillus \\
\hline GNP4K1 & Pinpoint & Opaque & Circular & Raised & Glisten & Undulate & - & Bacillus \\
\hline
\end{tabular}

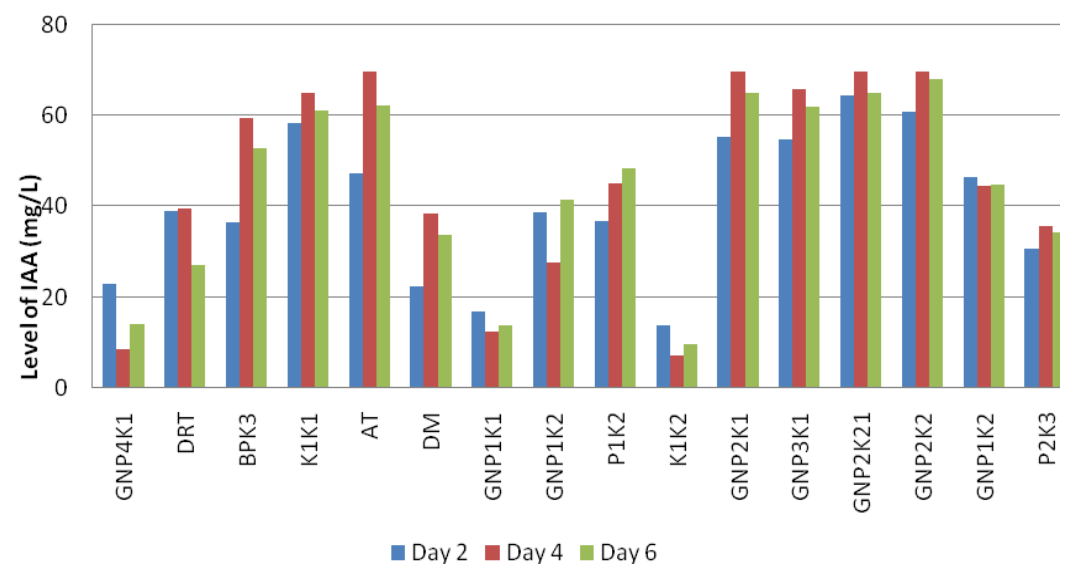

Figure 1. The production of IAA from various endophytic bacteria isolates 
The synthesis of IAA by microbes depends on the pathway of tryptophan, where tryptophan is used as a precursor and diverse taxonomic and metabolic tissue tissues. Some endophytic microorganisms have the potential to synthesize IAA to increase or stimulate growth when colonization occurs with endophytes (Shi et al., 2009). One of the main contributions of these microorganisms to plant growth is the production of molecules such as auxin (Spaepen et al., 2007). Indole 3 acetic acid (IAA) to auxin can stimulate growth, such as cell lengthening, cell division, and differentiation (Hasan et al., 2015). IAA-producing bacteria potentially affect the growth process from the amount of IAA in production and tissue sensitivity to IAA concentration changes.

\section{Introduction of IAA-producing endophytic bacteria to mungbean plants}

Isolates applied to mungbean plants with high IAA content of 16 isolates were selected for 5 isolates; application results to plants can be seen in Table 2 .

One-way ANOVA analysis results show that IAAproducing bacterial isolates did not affect the length of sprouts but influenced the number of roots. In low concentrations, IAA causes root and shoot elongation; if IAA concentrations are higher, the elongation of shoots and roots becomes inhibited (Moore, 1989). The addition of exogenous IAA affects the increase of IAA concentration in plants causing stunt length inhibition. In contrast to the number of roots, IAA concentrations in plants stimulate lateral root formation. IAA bacteria can loosen the cell wall of plants and consequently increase the number of roots that increase exudation, providing additional nutrients to support the growth of the bacterial rhizosphere. IAA bacteria stimulate the development of the root system of host plants. IAA production of isolates can improve the fitness of microbial plant interactions (Hasan et al., 2015).

Endophytic bacteria not only generate IAA but also increase the availability of plant nutrients such as nitrogen, phosphate, and other minerals, so that plant growth increases. The root is one of the most sensitive organs to IAA fluctuations and is responsible for increasing the number of exogenous IAA useful for the primary root elongation process, lateral root formation, and adventive root (Ryan et al. 2008) IAA is the major auxin hormone in plants that controls plant growth. In addition, many important physiological processes include cell enlargement and differentiation. Therefore, when administered to the plant, the IAA produced by the bacteria will affect the plant tissue's sensitivity.

In conclusion, there were 16 isolates of endophytic bacteria having the ability to produce IAA. The incubation time affected the IAA content produced by bacteria, and IAA-producing endophytic bacteria isolate affected the number of lateral roots. Still, it did not affect the length of the sprouts. The largest bacterial isolates stimulating the formation of lateral roots are isolates of $\mathrm{DM}$ and $\mathrm{K} 1 \mathrm{~K} 1$.
Table 2. The effect of some isolates of IAA producers on the growth of root length and number of roots

\begin{tabular}{lll}
\hline Isolat & Length of sprout & Number of roots \\
\hline AT & 16.025 & $15 \mathrm{bc}$ \\
DM & 15.025 & $24.75 \mathrm{a}$ \\
GNP2K2I & 15.425 & $19.5 \mathrm{ab}$ \\
K1K1 & 14.20 & $23.75 \mathrm{a}$ \\
P2K3 & 14.75 & $19.75 \mathrm{ab}$ \\
Control & 14.65 & $13.75 \mathrm{c}$ \\
\hline
\end{tabular}

\section{REFERENCES}

Ahemad M, Kibret M. 2014. Mechanisms and applications of plant growth promoting rhizobacteria: current perspective. J King Saud Univ Sci 26: 11-20.

Ambawade MS, Pathade GR. 2015. Production of Indole Acetic Acid (IAA) by Stenotrophomonas maltophilia BE25 isolated from roots of banana (Musa spp.). Intl J Sci Res 4 (1): 2644-2650

Duan J, Jiang W, Cheng Z, Heikkila JJ, Glick BR. 2013. The complete genome sequence of the plant growth-promoting bacterium Pseudomonas sp. UW4. PLoS ONE 8: e58640. DOI: 10.1371/journal.pone.0058640.

Hassan E, Alikhani HA, Hosseini HM. 2015. Indole-3-acetic acid (IAA) production trait, a useful screening to select endophyte and rhizosphere competent bacteria for rice growth promoting agents. MethodsX 2 (2015) 72-78

Jasim B, Joseph AA, John CJ, Mathew J, Radhakrishnan EK. 2013. Isolation and characterization of plant growth promoting endophyt bacteria from the rhizome of Zingiber officinale. 3 Biotech 4 (2): 197204.

Khan Z, Doty SL. 2009. Characterization of bacterial endophytes of sweet potato plants. Plant Soil 322: 197-207.

Lestari, P, Susilowati D N, Riyanti E I. 2007. Pengaruh hormon asam indol asetat yang dihasilkan oleh Azospirillum sp. terhadap perkembangan akar padi. Jurnal Agro Biogen 3 (2): 66-71. [Indonesian]

Luo SL, Xu TY, Chen L, Chen JL, Rao C, Xiao X, Wan Y, Zeng GM, Long F, Liu CB, Liu YT. 2012. Endophyte-assisted promotion of biomass production and metal-uptake of energy crop sweet sorghum by plant-growth-promoting endophyte Bacillussp. SLS18. App1 Microbiol Biotechnol 93: 1745-1753.

Mattos KA, Padua VLM, Romerio A, Hallack LF, Neves BC, Ulisses TMU, Barros CJ, Todeschin AR, Previat JO, Mendoca Previato L. 2008. Endophytic colonization of rice (Oryza sativa L) by the diazaotrophic bacteriu Burkholderia kururiensis and its ability. Ann Acad Bras Cienc 80 (3): 477-493.

Moore TC. 1989. Biochemistry and Physiology of Plant Hormones. Spinger-Verlag, Berlin.

Nath R, Sharma GD, Barooah M. 2013. Screening of endophyt bacterial isolates of tea (Camellia sinensis L.) roots for their multiple plant growth promoting activities, Intl J Agric Environ Biotechnol 6 (3): 371-376.

Pandey PK, Yadav SK, Singh A, Sarma BK, Mishra A, Singh HB. 2012. Cross-species alleviation of biotic and abiotic stresses by the endophyte Pseudomonas aeruginosa PW09. J Phytopathol 160 (10): 532-539.

Rana A, Saharan B, Joshi M, Prasanna R, Kumar K, Lata N. 2011. Identification of multi-traits PGPR isolates and evaluating their potential as inoculants for wheat. Ann Microbiol 61: 893-900.

Ryan RP, Germaine K, Franks AF, Ryan DJ, Dowling DN. 2008. Bacterial endophytes: recent developments and applications. FEMS Microbiol Lett 278 (1): 1-9.

Saepen S, Jos S, Roseline R. 2007. Indole-3-Acetic acid in microbial and microorganism and microorganism plant signaling. Department of Microbial and Moleculer Systems, Centre of Microbial and Plant Genetics, Belgium 
Shi Y, Lou K, Li C. 2009. Isolation, quantity distribution and characterization of endophyt microorganisms within sugar beet. Afr J Biotechnol 8: 835-840.

Taghavi S, Garafola C, Monchy S, Newman L, Hoffman A, Weyens N. 2009. Genome survey and characterization of endophyt bacteria exhibiting a beneficial effect on growth and development of poplar. Appl Environ Microbiol 75: 748-757.
Tarabily KA. 2008. Promotion of tomato (Lycopersicon esculentum Mill.) plant growth by rhizospherecompetent 1-aminocyclopropane-1carboxylic aciddeaminase-producing streptomyceteactinomycetes. Plant Soil 308: P 161-174.

Yarnaliza, Siregar MW, Priyanti N. 2010. Peran bakteri endofit penghasil IAA terseleksi terhadap pertumbuhan tanaman padi. Prosiding Seminar Nasional Biologi FMIPA USU, 219-228. [Indonesian] 